\title{
GAMBARAN PELAYANAN ADMINISTRASI PENDAFTARAN RAWAT JALAN PASIEN BPJS SELAMA MASA PANDEMI COVID-19 DI RUMAH SAKIT AL ISLAM BANDUNG TAHUN 2021
}

\author{
Mutiafani Hanafi", Wiwin Winarti, Kamila Rostiana Rihadatul 'Aisy \\ Politeknik Al Islam Bandung \\ Email : muthy71@yahoo.com
}

\begin{abstract}
ABSTRAK
Penelitian ini berjudul "Gambaran Pelayanan Administrasi Pendaftaran Rawat Jalan Pasien BPJS Selama Masa Pandemi Covid-19 di Rumah Sakit Al Islam Bandung Tahun 2021". Tujuan dari penelitian ini adalah untuk mengetahui pelayanan administrasi pendaftaran rawat jalan yang diberikan kepada pasien BPJS saat terjadi pandemi Covid-19. Penelitian ini dilaksanakan mulai dari bulan April-Juni 2021. Jenis penelitian yang digunakan yaitu menggunakan metode kualitatif dengan pendekatan deskriptif, sedangkan untuk teknik pengambilan datanya melalui proses kajian dokumen, wawancara dengan supervisor pendaftaran dan beberapa staf yang bertugas sebagai pelaksana dan observasi yang dilaksanakan di unit pendaftaran rawat jalan pasien BPJS. Data yang terkumpul kemudian dianalisis dan dideskripsikan secara rinci dan terstruktur. Hasil dari penelitian ini, proses pelaksanaan pelayanan pendaftaran selama pandemi mengacu kepada regulasi yang berlaku juga ketentuan yang telah dibuat oleh rumah sakit. Beberapa pelayanan pendaftaran di Rumah Sakit Al Islam yang dapat digunakan oleh pasien BPJS yaitu pendaftaran langsung, Pendaftaran via telepon, pendaftaran auto registrasi, rujukan antar fasilitas kesehatan, dan rujukan Internal. Berdasarkan data dapat disimpulkan bahwa pelayanan yang diberikan oleh Rumah Sakit Al Islam selama pandemi telah dilakukan penyesuaian pada regulasi untuk menegakkan protokol covid-19 sudah sesuai dengan regulasi yang berlaku dan dilaksanakan sesuai dengan standar prosedur operasional yang ditetapkan oleh pihak Rumah Sakit.
\end{abstract}

Kata kunci: Covid-19, Pasien BPJS, Pelayanan Administrasi RS, Pendaftaran, Rawat Jalan.

\begin{abstract}
The title of this research is "Overview of BPJS Outpatient Registration Administration Services during Covid-19 Pandemic at Al Islam Hospital Bandung in 2021". The purpose of this research was to determine the outpatient registration administrative services provided to BPJS patients during covid-19 pandemic. This research was conducted from April to June 2021. The research uses qualitative method with a descriptive approach, while the data collection technique is through a document review process, interviews with the registration supervisor and admission staffs also observations carried out in the outpatient registration unit of BPJS patients. The collected data is then analyzed and described in a detailed and structured manner. The results of this research are the process of implementing registration services
\end{abstract}


refers to the regulations and provisions constituted by the hospital. Registration services at Al Islam Hospital that BPJS patients can use are, Direct Registration, Telephone Registration, Autoregistration, Referrals between health facilities, and Internal Referrals. From these data it is concluded that the services rovided by Al Islam Hospital during the pandemic has made the necessary modification to the existing regulation to adhere covid-19 protocol, are in accordance with applicable regulations and implemented in accordance with the standard operating procedures set by the Hospital.

Keywords: BPJS Patients, Covid-19, Hospital Administration Services, Outpatient, Registration

\section{PENDAHULUAN}

Pandemi covid-19 memberikan dampak serius di banyak sektor di hampir seluruh belahan dunia, terutama pada bidang kesehatan. Pandemi Covid-19 sedang menguji ketahanan sistem pelayanan kesehatan di seluruh dunia termasuk Indonesia. Kemampuan dalam merespons secara cepat dan tepat menjadi kunci agar dapat melalui krisis ini dengan baik. Karena itu, pemerintah pusat, pemerintah daerah, industri rumah sakit, asosiasi rumah sakit, dan para manajer rumah sakit harus bersiap merespons serangkaian gelombang pandemi Covid-19 yang sedang dan akan menghantam (Irwandy, 2020).

Keberadaan fasilitas kesehatan sangat menentukan dalam pelayanan pemulihan kesehatan, salah satunya adalah rumah sakit, sesuai dengan yang tercantum dalam Undang-undang Republik Indonesia Nomor 44 Tahun 2009 disebutkan bahwa rumah sakit adalah institusi pelayanan yang menyelenggarakan pelayanan kesehatan perorangan secara paripurna yang menyediakan pelayanan rawat inap, rawat jalan, dan gawat darurat.

Pelayanan pendaftaran rawat jalan merupakan pelayanan pertama dan merupakan pintu gerbang rumah sakit, serta merupakan salah satu bagian dari pelayanan medik yang berinteraksi langsung dengan konsumen sehingga dapat memberikan kesan kepada konsumen terhadap mutu pelayanan secara umum. Pasien mengartikan pelayanan yang bermutu dan efektif adalah jika pelayanannya nyaman, menyenangkan, dan petugasnya ramah yang secara keseluruhan memberikan kesan kepuasan terhadap pasien.

Jaminan Kesejahteraan Nasional (JKN) yang dikelola oleh BPJS Kesehatan sejak diberlakukan di tahun 2014 hingga 1 November 2021 jumlah kepesertaannya telah mencapai 226,4 juta jiwa atau $83,18 \%$ dari total penduduk Indonesia (Kesehatan, BPJS Kesehatan, 2021). Hal tersebut menunjukkan layanan kesehatan lebih mudah diakses oleh masyarakat Indonesia. Dengan adanya Jaminan kesehatan masyarakat semesta, masyarakat dimampukan untuk mendapatkan layanan kesehatan.

Angka tersebut menunjukkan pengguna fasilitas BPJS Kesehatan di Indonesia sangat signifikan. Dengan demikian rumah sakit yang ada di Indonesia ditantang memberikan layanan terbaik dalam penyelenggaraan pelayan kesehatan bagi pasien peserta BPJS.

Rumah Sakit Al Islam Bandung merupakan rumah sakit yang sejak awal telah berkomitmen secara penuh dalam memberikan layanan kepada masyarakat sejak program ini pertama kali diluncurkan (Winarti, 2015). Pada tahun ke 6 pelaksanaannya, walaupun kebijakan BPJS kesehatan telah banyak mengalami perubahan, RSAI terus berkomitmen untuk melaksanakan pelayanan kesehatan kepada peserta BPJS, terlebih di masa pandemic perlu kehati-hatian dan protokol ketat dalam memberikan pelayanan. 


\section{.Rumusan Masalah}

Berdasarkan latar belakang dan fokus penulisan seperti yang telah diuraikan di atas, maka rumusan masalah yang akan disajikan pada penulisan ini adalah bagaimana pelayanan administrasi pendaftaran rawat jalan bagi pasien BPJS selama masa pandemi covid-19 di Rumah Sakit Al Islam?

\section{Tujuan Penelitian}

Untuk mengetahui pelayanan administrasi pendaftaran rawat jalan pasien BPJS di Rumah Sakit Al Islam selama masa pandemic covid-19.

Menurut Setyawan (2017:75) administrasi seringkali diartikan dalam arti sempit, yaitu sebagai kegiatan ketatausahaan, yaitu pekerjaan yang bersifat tulis-menulis belaka. Administrasi dalam arti yang luas, yaitu sebagai suatu proses kerjasama yang telah ditentukan sebelumnya, juga seringkali dipertukarkan penggunaan dan pengertiannya dengan "manajemen", yang merupakan proses pencapaian tujuan melalui dan dengan orang lain.

Menurut Windu (2015) dalam Saputra et.al. (2020:2-3) disebutkan bahwa pendaftaran pasien merupakan tempat pelayanan awal pasien yang akan berobat di rumah sakit. Bagian pendaftaran pasien rawat jalan merupakan salah satu bentuk pelayanan medis pasien dan tentunya rumah sakit harus dapat memberikan pelayanan yang baik. Berawal dari pendaftaran pasien akan dinilai apakah rumah sakit tersebut memiliki kualitas pelayanan yang baik atau sebaliknya.

Menurut Kepmenkes Nomor: 1165/MENKES/SK/X/2007 pelayanan rawat jalan adalah pelayanan pasien untuk observasi, diagnosis, pengobatan, rehabilitasi medik dan pelayanan kesehatan lainnya tanpa menginap di rumah sakit.

Menurut UU RI nomor 40 tahun 2004 BPJS ini merupakan penyelenggara program jaminan sosial di bidang kesehatan yang merupakan salah satu dari lima program dalam Sistem Jaminan Sosial Nasional (SJSN), yaitu Jaminan Kesehatan, Jaminan Kecelakaan Kerja, Jaminan Hari Tua, Jaminan Pensiun, dan Jaminan Kematian.

Menurut Undang-Undang Nomor 44 Tahun 2009 Rumah Sakit adalah institusi pelayanan kesehatan yang menyelenggarakan pelayanan kesehatan perorangan secara paripurna yang menyediakan pelayanan rawat inap, rawat jalan, dan gawat darurat.

\section{METODOLOGI PENELITIAN}

Jenis penulisan ini menggunakan metode deskriptif dengan pendekatan kualitatif, menurut Purnia dan Tuti (2020:23) metode deskriptif adalah metode riset yang bertujuan untuk menjelaskan suatu peristiwa yang sedang berlangsung pada masa sekarang dan juga masa lampau. Metode riset ini dapat dibagi menjadi dua, yaitu longitudinal (sepanjang waktu) dan Crow Sectional (Waktu tertentu). Maka dari itu penulisan ini berisikan penjelasan mengenai pelayanan pendaftaran rawat jalan pasien BPJS di Rumah Sakit Al Islam Bandung. Penulisan ini menggunakan 3 teknik pengumpulan data yaitu Kajian Dokumen yang berupa lembar SPO, lembar uraian tugas dan struktur organisasi, Observasi yang dilakukan di Unit Pendaftaran Rawat Jalan Pasien BPJS Rumah Sakit Al Islam Bandung, kemudian yang terakhir adalah wawancara. 


\section{HASIL DAN PEMBAHASAN}

Rumah Sakit Al Islam merupakan rumah sakit kelas B dengan jumlah bed sebanyak 227, dan menjadi rumah sakit rujukan PPK 3. Secara umum pendaftaran rawat jalan pasien BPJS berada di bawah instalasi rekam medik dan sistem informasi. Posisi dan kedudukan pelaksana pendaftaran BPJS tampak pada struktur organisasi tampak pada gambar 1 .

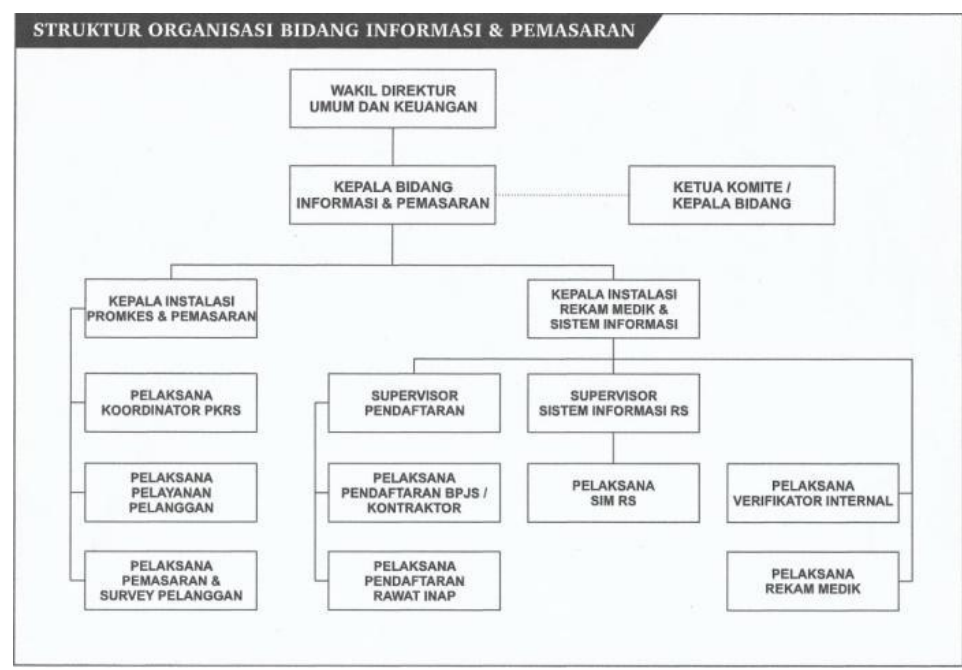

Gambar 1 Struktur Organisasi

\section{Standar Prosedur Operasional}

Untuk pelaksanaan pendaftaran rawat jalan pasien BPJS telah diatur dalam Dokumen SOP nomor 26/SPO/RSAI/III/2019, pada tanggal 27 Maret 2019 dengan tujuan 1. Tercapainya tata tertib administrasi dalam rangka upaya peningkatan mutu pelayanan penerimaan pasien dan pelayanan kesehatan di RS Al Islam Bandung; dan 2. Tersedianya prosedur bagi petugas administrasi pendaftaran rawat jalan pasien BPJS dalam melaksanakan kegiatan penerimaan pasien di RS Al Islam Bandung.

\section{Uraian Tugas}

Secara rinci uraian tugas petugas pendaftaran dapat dilihat dari gambar 2 di bawah ini:

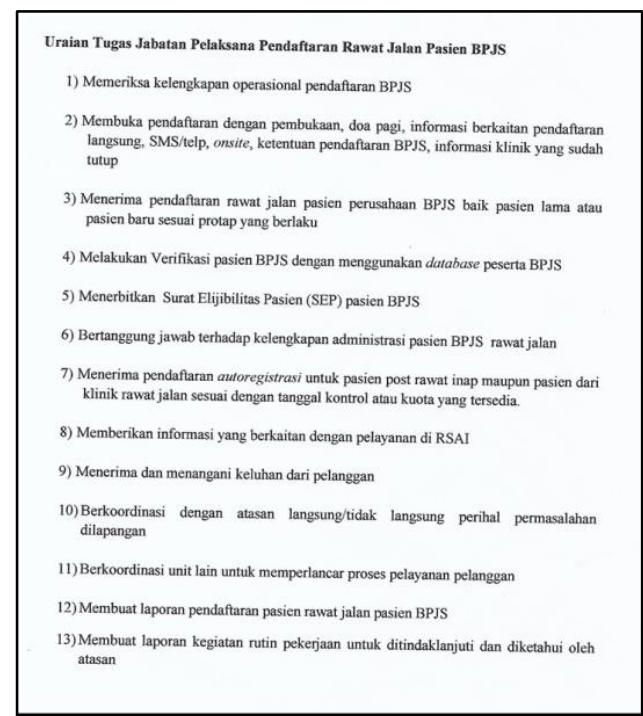

Gambar 2 Uraian Tugas 


\section{Pelaksanaan Pendaftaran Rawat Jalan Pasien BPJS}

Sumber daya manusia yang ditugaskan pada unit pendaftaran rawat jalan pasien BPJS ada 8 orang yang ditempatkan di loket A, B, C, D, E dan Via Telpon, dengan tugas dan fungsi sebagai berikut.

Tabel 1 Tugas dan Fungsi Loket di Instalasi Pendaftaran Rawat Jalan Pasien BPJS

\begin{tabular}{|c|c|c|}
\hline No & Jenis Loket & Keterangan \\
\hline 1 & Loket A & $\begin{array}{l}\text { Ditujukan untuk pasien yang baru pertama kali melakukan } \\
\text { pengobatan atau pasien lama yang belum melakukan pendaftaran } \\
\text { untuk melakukan pengobatan pada hari tersebut. }\end{array}$ \\
\hline 2 & Loket B & $\begin{array}{l}\text { Ditujukan untuk pasien yang sudah memiliki perjanjian di bulan } \\
\text { sebelumnya melalui pendaftaran autoregistrasi. }\end{array}$ \\
\hline 3 & Loket C & $\begin{array}{l}\text { Ditujukan untuk pasien yang sudah terdaftar melalui telepon, loket } \\
\text { ini digunakan untuk poli manapun kecuali jantung }\end{array}$ \\
\hline 4 & Loket D & $\begin{array}{l}\text { Loket ini dikhususkan untuk pasien geriatri, yaitu pasien yang telah } \\
\text { berusia } 70 \text { tahun atau lebih, loket ini melayani semua jenis } \\
\text { pendaftaran mulai dari pasien yang baru mendaftar, pasien } \\
\text { autoregistrasi ataupun pasien yang sudah mendaftar via telepon. } \\
\text { Namun nomor antrian D ini tidak akan berlaku apabila pasien tidak } \\
\text { ada di tempat, maka keluarga/wali yang mendaftarkan harus } \\
\text { mengambil antrian lain sesuai dengan penjelasan diatas. }\end{array}$ \\
\hline 5 & Loket E & $\begin{array}{l}\text { Loket ini dibuka mulai dari pukul } 11.00 \text { WIB sampai dengan } 14.30 \\
\text { WIB karena loket ini melayani untuk pasien yang melakukan } \\
\text { pendaftaran untuk } 1 \text { bulan kedepan, } 1-7 \text { hari sebelum pengobatan, } \\
\text { ataupun pasien yang akan membuat rujukan untuk faskes lain. } \\
\text { Loket ini bertujuan untuk memudahkan pasien yang mengalami } \\
\text { kesulitan pada saat membuat perjanjian via telepon, namun dengan } \\
\text { syarat membawa surat rujukan atau surat kontrol yang asli. }\end{array}$ \\
\hline 6 & Via Telepon & $\begin{array}{l}\text { Melakukan pelayanan pendaftaran untuk pasien yang mendaftar } \\
\text { melalui telepon dengan ketentuan jarak waktu 1-7 hari sebelum } \\
\text { pemeriksaan, dan pendaftaran ini berlaku untuk poli manapun. Dan } \\
\text { juga pendaftaran ini dapat digunakan oleh Pasien BPJS, Pasien } \\
\text { Kontraktor maupun Pasien Umum. }\end{array}$ \\
\hline
\end{tabular}

\section{Pelaksanaan Pendaftaran Rawat Jalan Pasien BPJS}

Rumah Sakit Al Islam Bandung dalam upayanya memberikan fasilitas yang terbaik untuk petugas maupun pasien BPJS yang akan melakukan pengobatan, adalah dengan memperhatikan aspek sarana dan prasarana, seperti mesin dan bahan yang digunakan dalam proses pendaftaran agar proses pendaftaran oleh petugas kepada pasien dalam berjalan dengan lancar.

Bagi pasien BPJS, untuk memudahkan proses pendaftaran rawat jalan, RSAI menyediakan tiga jenis pelayanan. Selain pendaftaran langsung, juga diberikan pendaftaran via telepon dan pendaftaran auto registrasi yang dilakukan di loket 6. Untuk pelayanan via telepon ditujukan untuk pasien BPJS yang telah terdaftar sebelumnya. Untuk pasien baru harus daftar langsung terlebih dahulu untuk pendataan pasien. Layanan melalui telepon dapat dilakukan beberapa hari sebelumnya, sehingga pasien akan mengetahui jadwal pasti kunjungan ke poli yang dimaksud dan pasien akan datang pada jadwal yang telah ditentukan. Sistem ini efektif dalam menghindari antrian yang berujung pada kerumunan sehingga memudahkan baik bagi pasien maupun rumah sakit. 
Untuk pendaftaran auto registrasi selama masa pandemi, sistem auto registrasi juga mengalami perubahan dalam rangka untuk mengurangi pembatasan kerumunan masyarakat. Pasien yang dalam masa sebelum pandemi biasanya kontrol satu minggu sekali, maka masa kontrol diperpanjang menjadi dua minggu hingga satu bulan sekali.

Di awal masa pandemi suasana rumah sakit tidak dapat dihindari dirasa mencengkam karena masyarakat merasa khawatir dan takut untuk datang ke rumah sakit. Untuk itu perubahan kebijakan dan penerapan protokol covid menjadi suatu keharusan untuk meminimalisir penyebaran di lingkungan rumah sakit dengan menerapkan prosedur tambahan. Prosedur tersebut tujuannya lebih kepada edukasi kepada masyarakat dan memberi pemahaman mengenai protokol kesehatan yang harus harus dipatuhi.

Langkah-langkah tersebut dimulai dari sejak di pintu masuk dan dilakukan secara ketat. Pengunjung wajib mengenakan masker medis mengingat rumah sakit adalah tempat orang datang untuk berobat dan resiko penyebaran virus lebih tinggi dibanding tempat lain. Setelah itu pengunjung diperiksa suhu tubuhnya dan mengisi lembar skrining serta menggunakan hand sanitizer yang telah disediakan. Apabila ada pengunjung yang demam, batuk atau pilek, mereka segera pasien diarahkan masuk ke area PINERE (Penyakit Infeksi Emerging dan Re-Emerging) atau penyakit yang infeksius.

Alur pendaftaran rawat jalan pasien BPJS di RSAI selama pandemi tidak mengalami perubahan, namun protokol covid diterapkan secara ketat. Prosedur tersebut seperti tampak dalam gambar 3.

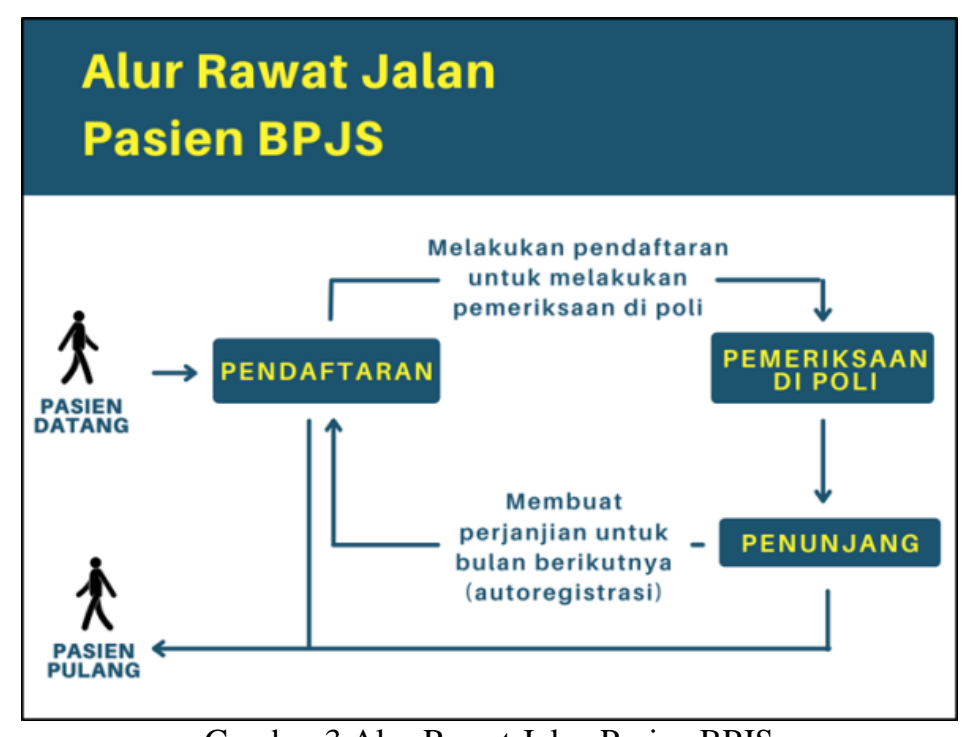

Gambar 3 Alur Rawat Jalan Pasien BPJS

Pasien rawat jalan BPJS pasien wajib membawa kartu BPJS yang masih berlaku, kartu berobat ke rumah sakit atau mengisi form pendaftaran untuk pasien baru dan surat rujukan dari faskes lain yang ditujukan untuk rumah sakit Al Islam atau Surat Keterangan Dalam Perawatan (SKDP). Setelah diterbitkan SEP maka pasien berhak mendapatkan pelayanan pengobatan di poliklinik yang dituju. Apabila pengobatan sudah selesai maka pasien dapat mengambil obat di farmasi atau melakukan pemeriksaan penunjang lainnya seperti lab atau radiologi.

Pada bagian auto registrasi tidak semua pasien mendapatkannya. Hanya poli dan dokter tertentu yang dapat melakukan auto registrasi. Sistem ini bertujuan untuk memudahkan pasien dalam membuat perjanjian dengan dokter di bulan berikutnya, dan bagi pasien yang tidak dapat 
melakukan auto registrasi maka opsi lainnya yaitu dengan membuat perjanjian melalui telepon dengan jarak waktu 1-7 hari sebelum jadwal berobat.

Proses pendaftaran pasien BPJS juga tidak mengalami perubahan, seperti yang terdapat pada gambar 4.

\section{Proses Pendaftaran Pasien}

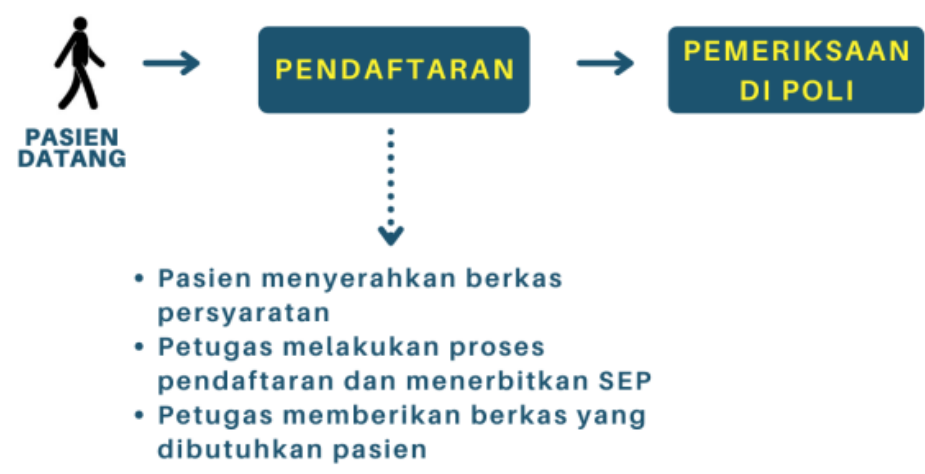

Gambar 4 Proses Pelayanan Pendaftaran Rawat Jalan

Tercantum dalam panduan praktis pelayanan kesehatan BPJS kesehatan bahwa cakupan pelayanan rawat jalan tingkat lanjutan pada bagian administrasi pelayanan meliputi biaya administrasi pendaftaran peserta untuk berobat, penerbitan surat eligibilitas peserta, termasuk pembuatan kartu pasien.

Menurut Peraturan Menteri Kesehatan Republik Indonesia Nomor 28 Tahun 2014 tentang Pedoman Pelaksanaan Program JKN dalam Prosedur Pelayanan pada Fasilitas Kesehatan Rujukan Tingkat Lanjutan (FKRTL), antara lain: a. Peserta datang ke Rumah Sakit dengan menunjukkan nomor identitas peserta JKN dan surat rujukan, kecuali kasus emergency, tanpa surat rujukan; $b$. Peserta menerima Surat Eligibilitas Peserta (SEP) untuk mendapatkan pelayanan; c. Peserta dapat memperoleh pelayanan rawat jalan dan atau rawat inap sesuai dengan indikasi medis; d. Apabila dokter spesialis/subspesialis memberikan surat keterangan bahwa pasien masih memerlukan perawatan di FKRTL tersebut, maka untuk kunjungan berikutnya pasien langsung datang ke FKRTL tersebut (tanpa harus ke FKTP terlebih dahulu), dengan membawa surat keterangan dari dokter tersebut; e. Apabila dokter spesialis/subspesialis memberikan surat keterangan rujuk balik, maka untuk perawatan selanjutnya pasien langsung ke FKTP membawa surat rujuk balik dari dokter spesialis/subspesialis; f. Apabila dokter spesialis/subspesialis tidak memberikan surat keterangan sebagaimana dimaksud pada poin (d) dan (e), maka pada kunjungan berikutnya pasien harus melalui FKTP; g. Fisioterapi dapat menjalankan praktik pelayanan Fisioterapi secara mandiri (sebagai bagian dari jejaring FKTP untuk pelayanan rehabilitasi medik dasar) atau bekerja di Fasilitas Pelayanan Kesehatan; h. Pelayanan rehabilitasi medik di FKRTL dilakukan oleh dokter spesialis kedokteran fisik dan rehabilitasi medik dapat diberikan kepada dokter yang selama ini sudah ditugaskan sebagai koordinator pada bagian/departemen/ instalasi rehabilitasi medik rumah sakit, dengan kewenangan terbatas sesuai kewenangan klinis dan rekomendasi surat penugasan klinis yang diberikan oleh komite medik rumah sakit kepada direktur/kepala rumah sakit; i. Apabila dikemudian hari rumah sakit tersebut sudah memiliki dokter spesialis kedokteran fisik dan rehabilitasi medik maka semua layanan rehabilitasi medik kembali menjadi wewenang dan tanggung jawab dokter spesialis kedokteran fisik dan rehabilitasi medik. 
Di samping permasalahan mengenai sistem adapun permasalahan lain yang disebut human error atau kesalahan dari petugas maupun pasien yang akan mendaftar, biasanya kesalahan yang berasal dari petugas adalah kurang teliti dalam mendaftarkan, miss comunication dengan pasien atau waktu kerja yang kurang disiplin, sedangkan kesalahan yang berasal dari pasien biasanya berkas yang kurang lengkap, salah waktu kunjungan atau bisa jadi pasien yang belum memahami alur rujukan berjenjang yang ditetapkan untuk pasien BPJS, jika terjadi permasalahan seperti itu maka petugas akan menjelaskan kepada pasien mulai dari letak kesalahan, regulasi yang berlaku hingga solusi untuk permasalahan tersebut, sebisa mungkin petugas akan menjelaskan secara perlahan dan jelas agar mudah dipahami oleh pasien dan tentunya tanpa ada pihak yang merasa dirugikan.

\section{KESIMPULAN}

Proses pendaftaran rawat jalan pasien BPJS Kesehatan selama masa pandemi tetap mengacu kepada regulasi yang berlaku dan juga ketentuan yang telah dibuat oleh rumah sakit yaitu Pendaftaran Langsung, Pendaftaran Via Telepon, Pendaftaran Auto Registrasi, Rujukan antar FASKES, dan Rujukan Internal. Kalaupun ada perubahan adalah pada pelaksanaan protokol kesehatan Covid-19 dan tambahan layanan via telepon bagi pendaftaran pasien lama dan pengurangan jumlah hari jadwal kontrol bagi pasien auto registrasi dengan interval yang lebih lama sebagai upaya untuk mengurangi kerumunan.

Kendala yang dihadapi selama proses pendaftaran baik itu disebabkan oleh petugas maupun yang disebabkan oleh pasien/wali yang mendaftar. Kesalahan yang berasal dari petugas adalah kurang teliti dalam mendaftarkan, miss comunication dengan pasien atau waktu kerja yang kurang disiplin, sedangkan kesalahan yang berasal dari pasien biasanya salah mengambil nomor antrian, berkas yang kurang lengkap, salah waktu kunjungan atau juga pasien yang belum memahami alur rujukan berjenjang yang ditetapkan untuk pasien BPJS.

Berdasarkan dari simpulan diatas, maka penulis memberikan beberapa saran kepada pihak rumah sakit yang kiranya dapat membantu di masa yang akan datang, diantaranya adalah pasien dan petugas satpam harus lebih teliti dalam memilih nomor antrian, agar proses pendaftaran dapat berjalan dengan lancar, lalu setelah melakukan proses pendaftaran petugas mengingatkan kembali kepada pasien tentang masa berlaku rujukan yang digunakan pasien, dan yang terakhir setelah melakukan proses auto registration, petugas diharapkan mengkonfirmasikan atau menuliskan perjanjian yang sudah dibuat dengan rinci, hal ini bertujuan agar tidak ada lagi pasien yang salah tanggal pada saat akan berobat, dan penulis harap para staf yang bertugas dapat mempertahankan atau bahkan meningkatkan kemampuannya dalam melayani pasien yang berobat di Rumah Sakit Al Islam Bandung.

\section{DAFTAR RUJUKAN}

Arianti, F. (2019). Pelayanan Rawat Jalan BPJS. Dipetik Mei 16, 2021, dari cermati.com: https://www.cermati.com/artikel/daftar-layanan-dan-penyakit-yang-ditanggung-dan-tidakditanggung-bpjs-kesehatan.

Badan Penyelenggara Jaminan Sosial Kesehatan. (2021). Kota Metro Jamin Akses Kesehatan Seluruh Warga melalui Program JKN-KIS. Dipetik Desember 15, 2021, dari https://bpjskesehatan.go.id/bpjs/post/read/2021/2133/Kota-Metro-Jamin-Akses-Kesehatan-SeluruhWarga-melalui-Program-JKN-KIS.

Irwandy (2020) dampak pandemi covid-19 hantam sistem layanan kesehatan dalam 4 gelombang dari National Geographic Indonesia https://nationalgeographic.grid.id/read/132255604/ 
Kesehatan, B. (t.thn.). Panduan Praktis Pelayanan Kesehatan. Dipetik Agustus 7, 2021, dari BPJS Kesehatan: kesehatan.go.id/bpjs/dmdocuments/0455038740193d957326594ea0d87b5e.pdfN

Notoatmojo, S. (2010). Metodologi Penelitian Kesehatan. Jakarta: Rineka Cipta.

Organisasi, B. (t.thn.). Uraian Tugas. Dipetik Agustus 7, 2021, dari Bagian Organisasi: https://weborganisasi.jogjakota.go.id/page/index/uraian-tugas

Permenkes. (2019). Pengertian Rumah Sakit Menurut Permenkes. Dipetik Mei 15, 2021, dari jogloabang: https://www.jogloabang.com/pustaka/uu-44-2009-rumah-sakit

Purnia, D. S., \& Tuti, A. (2020). Metode Penelitian: Strategi Menyusun Tugas Akhir. Yogyakarta: Graha Ilmu.

Rachmayanti, L. (2016). Gambaran Umum Pelayanan Pendaftaran Pengguna BPJS Rawat Jalan di Rumah Sakit Al Islam. Dipetik Juli 19, 2021, dari Repository UIN Syarif Hidayatullah Jakarta: https://repository.uinjkt.ac.id/dspace/bitstream/123456789/32981/1/LAILY\%20RACHMA YANTI-FKIK

Saputra, M. G., Kusdiana, A., Suratmi, \& Yuniar, I. (2020). Pengaruh Pelayanan Pendaftaran Online Terhadap Kepuasan Pasien Rawat Jalan di Rumah Sakit Muhammadiyah Lamongan. Journal Of Health Care, 2-3.

Sarwono, J. (2018). Metode Penelitian Kuantitatif dan Kualitatif Edisi 2. Yogyakarta: Suluh Media.

Setyawan, E. (2017). Sekertaris dan Administrasi Perkantoran. Yogyakarta: Istana Media.

Winarti, W. (2015). Implementasi Program BPJS Kesehatan di RS Al Islam Bandung. Bandung. 